\title{
Martial Virtues and Whistle-Blowing: Loyalty Misplaced and Courage Misunderstood
}

\section{Bojové ctnosti a whistleblowing: ztracená věrnost a nepochopená odvaha}

\section{Dragan Stanar}

Abstract: This paper aims to explain the tension between the phenomenon of whistle-blowing and military values, embodied in core martial virtues of loyalty and courage, which are integral in all armies. By defining these virtues in the military context, the author demonstrates how expressing dissent in the military is not necessarily opposed to loyalty and courage, but rather that it is necessary if conflict of different loyalties is properly managed and if courage is properly understood. Only by ensuring that armed forces are led by those who truly understand military values and martial virtues, and that whistle-blowing can be both patriotic and heroic, can we strive for a lasting peace. By courageously expressing loyalty to his nation, institution and profession, a soldier may act heroically by blowing the proverbial whistle.

Abstrakt: Cílem této práce článku je vysvětlit napětí mezi fenoménem whistleblowingu a vojenskými hodnotami ztělesněnými v základních bojových ctnostech věrnosti a odvahy, které jsou nedílnou součástí všech armád. Definováním těchto ctností ve vojenském kontextu autor ukazuje, že vyjádření nesouhlasu $v$ armádě nemusí nutně odporovat věrnosti a odvaze, je však především nutné, aby byl konflikt rozdílných loajalit přiměěeně zvládnut a odvaha správně pochopena. Pouze při zajištění, že ozbrojené síly budou vedeny těmi, kdo skutečně chápou vojenské hodnoty a bojové ctnosti a také to, že whistleblowing může být vlastenecký i hrdinský, můžeme usilovat o trvalý mír. Odvážným vyjádřením věrnosti svému národu, instituci a profesi může voják hrdinsky jednat i tehdy, když zapíská na př́ślovečnou píštalku.

Key words: Whistle-Blowing; Military; Virtues; Courage; Loyalty.

Klíčová slova: Whistleblowing; armáda; ctnosti; odvaha; věrnost. 


\section{INTRODUCTION}

Topic of virtues has been present in moral philosophy since its beginnings. The notion of virtue derives from the Latin term Virtus, meaning excellence or capacity, and signifies "a disposition or a pattern in someone's character or personality that leads them to act morally"1. Virtues are admirable traits, cornerstones of moral character. Virtues were at the focus of interest of many ancient philosophers, especially Greek philosophers who attempted to define and develop $\alpha \rho \varepsilon \eta^{2}$. Development of virtues and their role in life represent the foundation of a normative ethical theory that we call Virtue ethics. Virtue ethics gradually gave way to deontological and utilitarian theories, but re-emerged as a significant factor in the $20^{\text {th }}$ century moral philosophy with authors like Foot, Maclntyre, Anscombe, etc. Despite the virtue ethics comeback normative theories of duty and utility are still predominant in moral philosophy. Nevertheless, virtue ethics has been essential in one particular area of ethics - military ethics. Following Aristoteles's ideas, "military ethical training emphasizes formation of strong moral character rather than sets of rules"3. There seems to be virtually no military ethics curriculum without significant sections regarding virtue development, with more than a few of them entirely based on virtues as "most of today's militaries put their money on character building in trying to make their soldiers, airmen, sailors, and marines virtuous" ${ }^{4}$. Military virtues are integral to military profession, and their development is one of the highest-order tasks of military training.

The phenomenon of organizational dissent in social institutions has become an interesting ethical problem, but it seems that dissent poses an unparalleled ethical problem when expressed in the military. This is quite expected, given the fact that the nature and role of the military is also unparalleled in society. But how does dissent relate to virtues, that are central to military identity? The military represents "one of the most powerful and most cohesive moral communities in modern society, precisely because its members as individuals identify primarily as members of an army... military virtues are a part of these personal identities" ${ }^{\prime 2}$, meaning that they transcend professional virtues of an organization. Is dissent even compatible with martial virtues, carefully instilled and developed in soldiers by their organizations? Is it even compatible with the military itself? The reason that got us interested in exploring this relationship between dissent and military virtues are the attitudes expressed by senior-year Military Academy cadets, generation after generation, country to country, whenever dissent and whistle-blowing in

1 Van Hoof, S. Understanding Virtue Ethics. Slough: Acumen Publishing Limited, 2006, p.1.

2 Notion of ápєtń was central in Greek philosophy, signifying all forms of excellence.

3 Schulte, P. Morality and War. In: J. Lindley-French and Y. Boyer (ed.). The Oxford Handbook of War. Oxford: OUP, 2012, p. 110.

4 Olsthoorn, P. Military Ethics and Virtues. London: Routledge, 2011, p. 4.

5 Фатић, А. Савремена технологија ратовања у светлу хришћанског морала. In Б. Гроздић (ed.). Православље и рат. Београд: МЦ Одбрана, 2017, р. 120. 
the military are discussed ${ }^{6}$. It is not just the fact that the majority of cadets frown upon whistle-blowers and strongly disapprove of their actions that is curious, but the fact that they allude to military virtues as their arguments in these discussions, particularly the virtues of loyalty and courage. These two are precisely the military virtues that are continuously being instilled in them from the moment they enter the system, and that will continue to be nurtured by the military as long as they are a part of it. Such attitudes are not solely reserved for cadets, rather they are shared by officers, NCOs and soldiers. The perception of dissent and whistle-blowing in the military has everything to do with how virtues of loyalty and courage are understood by those who are proud to call themselves soldiers ${ }^{7}$. Are we creating such a paradoxical narrative in which military virtues of loyalty and courage are actually preventing soldiers from doing the morally right thing? Are they understanding the virtue of courage properly, and to whom are they taught to be loyal?

\section{LOYALTY AND COURAGE}

Virtues of courage and loyalty are present in ethical codes, lists of values, codes of conduct, soldier's creeds, and similar documents of all modern militaries - "Not surprisingly, it is this virtue of courage that figures, together with loyalty and honour, prominently on the lists of virtues and values of most armed forces" 8 . The two are present in The Army Values ${ }^{9}$ of the US Army, in the Department of the Navy Core Values Charter ${ }^{10}$, in the Values and Standards of the British Army, in the Code of Honor ${ }^{\mathbf{1 1}}$ of the Serbian Armed Forces, etc. Mompeyssin published a comparative study in 2014, in which he compared documents regarding soldiers' codes of conduct from 17 militaries. One of the "many common points"12 in these documents is the presence of courage and loyalty. Another comparative study ${ }^{13}$, published a year later revealed the same as they went through the codes of British, Canadian, German, Dutch, Russian, French, Spanish, Portuguese, and American militaries. Courage and loyalty are cornerstones of all modern

6 After speaking and corresponding with numerous colleagues who teach ethics at different military academies, we found this phenomenon to be inherent to all militaries.

7 We use the term soldier to signify all those serving in military uniforms.

8 Olsthoorn, P. Military Ethics and Virtues, p. 44.

9 US Army. The Army Values. [viewed date: January 20th, 2021] available at: https://www.army.mil/ values/

10 In this Charter, loyalty is actually listed as a manifestation of courage, something that is quite interesting for our topic. US Navy. Navy Core Values Charter. [viewed date: January $20^{\text {th }}, 2021$ ] Available at: https:// www.secnav.navy.mil/Ethics/Pages/corevaluescharter.aspx

11 Serbian Armed Forces. The Code of Honor. [viewed date: December $11^{\text {th }}, 2020$ ] available at: http://www. mod.gov.rs/multimedia/file/staticki_sadrzaj/tradicija/2020/Kodeks_casti_pripadnika_VS.pdf

12 Mompeyssin, P. Soldier's codes of conduct in different countries around the world. Journal of Defense Resources Management. 2014, (5), p.6.

13 Bouzid, H. et al. Toward a European code of conduct for military and peacekeeping forces. In G. Lucas (ed.). Routledge Handbook of Military Ethics. London: Routledge, 2015, p. 194-207. 
military ethical codes, as "these are the twin virtues that form the core of military honour, from which the other virtues (obedience, integrity, honesty) are derived"14. But it is not just military organizations that rely on these two core values, they are likely to have been ever-present in military culture since the first warriors. In her book The Code of the Warrior ${ }^{15}$, French takes us on a journey from ancient Greece and Rome across the Vikings and Native Americans to Chinese warriors and Samurai, in an attempt to separate warriors from murderers and soldiers from killers using the warrior's code. We see that courage and loyalty were essential martial virtues for warriors from all eras and all corners of the world. These two virtues are not "merely contingent, but also evolve organically from the nature of that (military) profession; loyalty and courage are not virtues or traits that might be replaced with any others. These traits are essential to being a member of the military; one cannot be a good member of the military and fulfil one's role without them"16.

\section{LEVELS OF LOYALTY}

All virtues have always been notoriously difficult to define. Opinions on loyalty differ greatly - from considering loyalty to be "not a virtue per se"17, to those perceiving it as a "virtue that is absolutely central to military service"18. The author of the latter formulation offers a definition of loyalty that is convenient and advantageous to our research - "Loyalty involves a willingness to bear risks and make sacrifices for the sake of that to which one is loyal"19, and we shall therefore use it in our analysis. In the context of dissent and whistle-blowing the crucial task is to identify to whom or to what a soldier is loyal, and see if dissent is an expression of disloyalty. The first level of loyalty in the military is the one without which "the military cannot function efficiently" 20 and the one that is most manifest in warrior ethos, warrior legends, the very essence of warrior culture - loyalty to one's unit, one's comrades. This is the primary understanding in military institutions, as it is necessary for successful integration, creating unit cohesion and forming a bond. We shall refer to this type of loyalty as "group loyalty". Being loyal to one's comrades and to one's superiors is perceived as a driving force behind all valour

14 Kaurin, P.M. The Warrior, Military Ethics and Contemporary Warfare: Achilles Goes Asymmetrical. London: Routledge Taylor and Francis Group, 2016, p. 40.

15 French, S.E. The Code of the Warrior: Exploring Warrior Values Past and Present. Lanham: Rowman and Littlefield Publishers, 2003.

16 Shanks-Kaurin, P. Questioning Military Professionalism. In N.K. Finney and T.O. Mayfield (ed.). Redefining the Modern Military. Annapolis: Naval Institute Press, 2018, p. 27.

17 Olsthoorn, P. Military Ethics and Virtues, p. 91.

18 Sparrow, R. War without Virtue. In B.J. Strawser (ed.). Killing by Remote Control: The Ethics of an Unmanned Military. Oxford: OUP, 2013, p. 90.

19 Ibid.

20 Kaurin, P.M. The Warrior, Military Ethics and Contemporary Warfare, p. 45. 
in the field, behind risking one's life and self-sacrifice. There is a common theme of the proverbial "band of brothers" in practically all war tales. What most soldiers later tell is that in the moment of the battle, when their lives are hanging on by a thinnest of threads and when the difference between life and death is often plain dumb luck, soldiers fight for their comrades, for the man next to them. This poetic bond between men in the field, forged by continual imminent danger and the so-called phenomenon of proximity to death, was perhaps most prominently and quite beautifully described by Shakespeare, in his acclaimed play Henry $V$, through the mouth of King Henry, who, in an attempt to encourage and embolden his troops before the battle, famously proclaimed "...We few, we happy few, we band of brothers; for he today that sheds his blood with me shall be my brother, be he ne'er so vile..." ${ }^{\mathbf{2 1}}$. Loyalty to one another is one of the key factors that keeps units from falling apart at the first sight of peril, and what keeps men pushing forward, as they know that their "brothers in arms" will not abandon them. Due to the pivotal roles that loyalty to fellow-soldiers and group cohesion play in all military operations, loyalty is accentuated on every level of military education and training. This level of loyalty has been the most important to the majority of soldiers in history. If we then place group loyalty in the previously mentioned definition, it would mean that loyalty implies willingness to bear risks and make sacrifices for the sake of the unit and comrades. Few would argue that there is anything wrong with such an understanding. But soldiers must be loyal to more than just their units and their commanders.

"Second level" loyalty demanded of every soldier is loyalty to the traditions and reputation of his profession. Not just to the tradition of the abstract idea of a soldier's profession, but to the tradition of a particular army, or even a particular unit - Marines (US Navy), Rangers (US Army), Cossacks (Russian Military), Gurkhas (British Army), Iron Regiment (Serbian Army), etc. These units are not necessarily elite or special forces units, but such units usually tend to take extra care to preserve their reputations and maximize group loyalty. Military organizations of many nations have centuries-long history and proud warrior traditions that have substantial impact on behaviour of their current members. Therefore, a nation's military history represents a significant factor, as “there is something more visceral about military history... history reminds people that they are part of something bigger and older than they are, in which those going before have set standards of conduct and behaviour that today's people are expected to keep up" 22 . Once an individual becomes a soldier, a member of a particular unit, he must respect and uphold the traditions and image of something that is older and greater than himself. Many a soldier before him has shed blood and laid his life down in heroic endeavours and such sacrifices are woven into the identity of his unit or army and it comes as no surprise that "the motivation for individual warriors to remain true to their code often comes from their desire not to betray the memory of the warriors who came before

21 Shakespear, W. Henry V. Jefferson City: American Book Company, 1914, p. 84.

22 Anglim, S. An Educated Military: Professional Education and the Profession of Arms. In N.K. Finney and T.O. Mayfield (ed.), Redefining the Modern Military: The Intersection of Profession and Ethics. Annapolis: Naval Institute Press, 2018, p. 164. 
them"23. We shall call this second level of loyalty to one's military institution - loyalty to warrior traditions or loyalty to profession. This type of loyalty may seem too distant and abstract for soldiers to grasp, but it has proven to be very important. French writes about a young Marine, shaken by deaths of his fellow Marines in Vietnam, who held a rifle at the head of a non-combatant. He only lowered his weapon when his officer told him "Marines don't do that" ${ }^{24}$, reminding him that his actions must be compatible with the proud traditions of US Marines. He was reminded of who he represents in his uniform. It is not just personal morality and warrior image that is being compromised in such cases, but also the identity of entire units or even armies. Again, it doesn't have to be loyalty to traditions of some special-forces unit, it can be loyalty to entire armies - we can easily imagine an officer saying - Serbian officers don't do that, Romanian soldiers don't do that, Czech warriors don't do that, and achieving the same effect.

Finally, the "third level" of loyalty signifies loyalty to one's society, or better formulated, to one's nation - "national loyalty". Purpose of a soldier must be to bring good to his nation via establishment or preservation of a lasting peace - "If understood as an institution whose goal is to maintain peace via deterrence, and to achieve peace via fighting against those who make peace impossible, then every army must subordinate its manner of fighting to the possibility of achieving peace"25. Soldiers' primary allegiance is to their nations and to a good, lasting peace. Much has been written in recent years about the role of soldiers in the quest for peace - soldiers, even lower-level non-commissioned officers, have been recognized as factors of peace, as "strategic corporals" $\mathbf{2 6}$, and their behaviour in war as crucial for the possibility of establishing lasting peace, instead of short-term truces. Armed forces are now instruments of creating peace, not just winning wars. By respecting the International humanitarian law and limits of Jus in Bello, soldiers pave the way for peace that will come. By doing so, they remain loyal to their society, which gave them the mandate to kill and injure in war, but only for the purpose of peace. Soldiers remain loyal only if they protect the sacred trust invested in them by their nations, i.e. only if they exercise their unique discretion ${ }^{\mathbf{2 7}}$ in the interest of their nation "the relationship of trust between the military and the state is based on an understanding that the military will employ its monopoly over the knowledge and skills to use force only in the furtherance of the interests of the nation.... The state trusts individual

23 French, S.E. The Code of the Warrior, p. 16.

24 Ibid. p. 14.

25 Stanar, D. Paramilitary organizations and private military companies in war: How to restrain what you do not control? In P. Mileham (ed.). Jus Post Bellum: Restraint, Stabilisation and Peace. Leiden: Brill Nijhoff, 2020, p. 362.

26 This notion was introduced by Krulak, who recognized that in modern warfare in-field decisions of soldiers can have strategic implications. Krulak, S, The Strategic Corporal: Leadership in the Three Block War. Marines Magazine, 1999, (1), p. 1-7.

27 Soldiers enjoy a fiduciary relationship with the state - "The exercise of discretion is also the hallmark of fiduciary relationships, where the principal allows the fiduciary to exercise discretion that affects the interests of the principal“" Brick, J. The Military Profession: Law, Ethics, and the Profession of Arms. In N.K. Finney and T.O. Mayfield (ed.). Redefining the Modern Military: The Intersection of Profession and Ethics. Annapolis: Naval Institute Press, 2018, p. 44. 
members of the military profession to use their expertise and to behave in a manner that is consistent with the interests of the state" 28 .

The interest of a nation is served if immoral and illegal behaviour within the military is prevented or reported. Of course, there are instances in which the decision not to report provides a tactical advantage; but on a strategic level, it is never in the interest of a nation to plant seeds of future conflicts.

There is also something that is called "loyalty to principle". We do not negate the existence of this level of loyalty, but find it to be difficult to apply in the military, especially in times of war. The principle of justices, which is the most common principle taken as an example when discussing principle loyalty, can be problematic for soldiers in times of war when justice of war is virtually impossible to define. In modern times war cannot be defined easily, and it is particularly difficult to draw the line between a state of war and a state of peace. Probably the most famous definition of war as "continuation of policy by other means" ${ }^{29}$ forged by the legendary von Clausewitz, is said to be outdated. The reformulated version of his definition has been lauded as ideal for the modern world "policy is the continuation of war by other means"30. Subversive activities, "soft power", "public diplomacy", and many other forms of interaction in international relations are all activities short of war, but can form a type of a perpetual state of war, particularly for those in the military. Hence, every action of those in the military, in any type of modern "conflict", is viewed through the prism of war, despite the fact that there is no mass armed conflict currently ongoing. It seems unreasonable to demand of a soldier to know what the just side is in war or this state of "latent war" in peace. All sides are convinced of their justness, and the unique state of war can provide utilitarian justification for pretty much every action under the veil of proportionality and collateral damage as soldiers face "the abyss of utilitarian apologetics for large-scale murder"31. In this situation, pretty much everything can be justified with "loyalty to principle" of justness and the lesser evil argument. As long as soldiers remain loyal to the highest interest of their nations, and apply violence only as means of achieving a lasting peace, we can argue that they remain loyal to the principle.

\section{When loyalties conflict}

Three levels of loyalty usually go hand in hand with each other. All legendary war stories about heroism and loyalty are cases in which individuals displayed loyalty on all three levels. But, is it possible for these loyalties to conflict? Is it possible that soldiers at times face the challenge of choosing one loyalty over another, and what should they do when such events unfold? Phenomenon of whistle-blowing represents precisely such a scenario - a scenario in which individuals find themselves facing an often times insolvable problem - whom should I remain loyal to - group, profession or nation? When actions of one's group members conflict with values of his profession and interests of his

28 Ibid. p. 43-44.

29 von Clausewitz, C. On War. Oxford: OUP, 2007, p.28.

30 This phrase is attributed to Michael Foucault.

31 Nagel, T. Mortal Questions. Cambridge: CUP, 1979, p. 56. 
nation, one must decide either to stay loyal to the group or to stay loyal to his profession and nation. In military context, the value of group loyalty is overwhelmingly emphasized at the expense of other loyalties as unit cohesion can mean the difference between success and failure. On the flip side, "the dynamics of loyalty and tight unit cohesion can contribute to war crimes and atrocities" ${ }^{\mathbf{3 2}}$ as it represents a powerful factor working against speaking out and blowing the whistle in favour of silence and cover-ups. When a military member does something that is in conflict with professional and institutional values and interests of his nation, it is he who is disloyal, both to his profession and nation. Why should then anyone be expected to remain loyal to a group member who is being disloyal to tradition and nation? It is our view that loyalty to profession and loyalty to nation are condicio sine que non of group loyalty, and that when some group members become disloyal to their profession and nation, there can be no justified group loyalty. Second and third level loyalties are prerequisites for first level loyalty. Moreover, a soldier's duty is to prevent behaviour that is detrimental to his profession or nation, and to report it; this is completely in accordance with loyalty because every military "needs people who blow the whistle if necessary... it needs, much more frequently so, soldiers who are willing to correct a colleague when they think him wrong, or even report him if necessary"33. Their militaries and their nations are the beneficiaries of them performing their duties. Remaining loyal to one's nation and tradition when they are conflicted with group loyalty is the only proper way to manage situations of loyalty conflict. We agree with authors who claim that "the whistle-blower is not being disloyal, but someone who is not led (astray) by loyalty" 34 but add that while not being led astray by group loyalty, the whistle-blower remains loyal to his profession and nation. Placing group loyalty above every other loyalty is a recipe for disaster. This represents failure of loyalty conflict management, and numerous historical examples "showed the working of group loyalty without loyalty to the larger values and institution and the consequences of such loyalties" 35 .

Can we expect of soldiers to recognize these levels of loyalty, and to properly manage loyalty conflicts? We firmly believe that every soldier intuitively knows what the right course of action is in such situations, and that excessive group loyalty is the thing standing between him and the right decision. Group loyalty is the greatest contributor to akrasia $^{36}$ or the lack of moral courage. Again, we go back to cadets from first pages of this paper. Despite a huge majority of them referring to their hypothetical colleague who blows the whistle as disloyal, things change once we eliminate the burden of group loyalty. The easiest way to do this is to place a member of some different military in the example. For example, no one ever said that actions of Sergeant Joe Darby in Iraq were cowardly or disloyal. On the contrary, his famous whistle-blowing on torture methods and obscene abuse of prisoners in Abu Ghraib are seen as heroic. He is perceived

\footnotetext{
32 French, S.E. The Code of the Warrior, p. 50.

33 Olsthoorn, P. Military Ethics and Virtues, p. 51.

34 Ibid. p. 69.

35 French, S.E. The Code of the Warrior, p. 51.

36 Akrasia (Greek $\alpha$ k $\rho \alpha \sigma i \alpha$ ) signifies weakness of will to act on moral judgment.
} 
as a "decent man", "honest soldier", etc. by those outside the US military. No matter how many examples such as this one we went through, cadets always recognized that group loyalty must not restrict other levels of loyalty. Often, they even reach the fair conclusion that immoral actions and cover-ups are detrimental to interests of the nation to which these individuals belong to. Even in the most extreme case of group disloyalty that we know of, the case of Dutch soldier Poncke Princen, who did the unthinkable and switched sides in the middle of conflict between colonial Netherlands and guerrillas in Indonesia, his actions are understood as manifestations of his loyalty to the principle of justice. So, if almost all of them know perfectly well that group loyalty cannot be used to justify immoral actions and disloyalty to profession and nation and if they see individuals who act on their professional and national loyalties against their group-members as moral and just, why is it so difficult for them to speak out against misbehaviour and crimes of their own comrades? Admittedly, there are multiple factors - from psychological to sociological, but if we use the favourite philosophical principle of novacula Occami ${ }^{37}$ on this complex issue, we will arrive to the other indispensable military virtue - courage, more specifically, lack of it.

\section{MORAL COURAGE}

To define courage is to solve a centuries long riddle. Courage was one of the central virtues in ancient Greek civilization, but even the wisest of philosophers found it hard to define. When faced with Socrates and his famous maieutic method, one of the Greek generals in Plato's dialogue on courage, Laches, offers many definitions of courage, but finally concludes - "for I fancy that I do know the nature of courage; but, somehow or other, she has slipped away from me, and I cannot get hold of her and tell her nature" $\mathbf{3 8}$. Aristotle famously defined courage in the same manner that he defined all virtues as midpoints between exaggerated extremes. In the case of courage, the middle point stands between excessive boldness or recklessness on one side of the spectrum and excessive fear or cowardice on the other. When searching for the appropriate definition of courage, we came across a brilliant book called The Mystery of Courage, in which its author collected more than a hundred attempts to define courage. He highlights that courage is "the most frequent theme in all world literature" ${ }^{39}$, that it has been one of the most important virtues in all known cultures, but in the end resorts to citing the words of Tim O'Brien, a Vietnam veteran, regarding the mystery of courage - "It is hard to be brave. It is hard to know what bravery is" $\mathbf{4 0}^{\mathbf{4 0}}$. It is a painstaking endeavour to try to define courage, so instead of pursuing such an effort, we shall rely on Sidgwick's minimal

37 The principle of Occam's Razor is the principle of choosing the simplest of all possible hypothesis.

38 Plato. On Socrates: Selected Writings. Lanham: Collectors Library, 2004, p. 121.

39 Miller, W.I. The Mystery of Courage. Cambridge: HUP, 2002, p. 8.

40 Ibid. 
explanation of courage, as "a disposition to face danger of any kind without shrinking"41. In military context, courage is more pivotal than in any other context, as it represents "the most central virtue to any discussion of military ethics" ${ }^{\mathbf{4 2}}$. Courage is a "martial virtue par excellence" $\mathbf{4 3}$ and entire military identities are built around it. To be courageous is the first prerequisite of being a soldier, just like being just is the first prerequisite of being a judge. Drawing a parallel between academics and soldiers, Maclntyre notes that "truthfulness is the indispensable professional virtue of all academic researchers, as courage is the indispensable professional virtue of soldiers" ${ }^{44}$. But if courage is so vitally important for the military, and if it represents the cornerstone of all military training, why do so few military members actually have the courage to express dissent when their fellow soldiers become disloyal to their nations? The answer partially lies in the type of courage the military emphasizes - physical courage. Physical courage means everything in the military and it is highly revered, not just in military circles, but by entire nations. But whistle-blowing requires an additional form of courage - moral courage. Moral courage is a phrase coined relatively late in English language, not before the nineteenth century, and it signifies the ability to "face the pains and danger of social disapproval in the performance of what someone believes to be duty" ${ }^{\prime 45}$. One requires moral courage to resist conformism and face group and public shaming, derision, embarrassment, and other consequences of whistle-blowing. In military environment, especially in critical times, these consequences can be perceived by soldiers as worse than severe physical pain or even death! As we mentioned, being courageous is probably the most important thing for a soldier, and from it follows that "to be branded a coward is amongst, if not, the worst insults that can be levelled at a warrior"46. Thus, it is no wonder that many soldiers think that being physically courageous is easier than being morally courageous, as it is "easier to be shot than to be laughed at and scorned"47. Throughout history, men have died in numbers to avoid shame and embarrassment and to prove their worthiness to the group, so we must not be surprised with the power and force of such fears. Surely, one must be extremely morally courageous to consciously face such consequences. It is precisely this type of courage, moral courage, that is necessary for proper loyalty conflict management. Only a brave person can remain loyal to his warrior traditions, his profession and his nation's interests even if it means putting his entire family on the edge of poverty, being ostracized, and called a coward by his own comrades.

Moral courage is different than physical courage but they do not necessarily exclude each other - on the contrary, moral courage often demands physical courage. There is no

41 Sidgwick, H. The Methods of Ethics, 7th ed. London: MacMillan and Co, 1907, p. 353.

42 French, S.E. The Code of the Warrior, p. 24.

43 Sparrow, R. Drones, Courage, and Military Culture. In G. Lucas (ed.). Routledge Handbook of Military Ethics. London: Routledge Taylor and Francis, 2015, p. 383.

44 MacIntyre, A.C. Military Ethics: A Discipline in Crisis". In G. Lucas (ed.). Routledge Handbook of Military Ethics. London: Routledge Taylor and Francis, 2015, p. 5.

45 Sidgwick, H. The Methods of Ethics, p. 345.

46 French, S.E. The Code of the Warrior, p. 24.

47 Miller, W.I. The Mystery of Courage. Cambridge: HUP, 2002, p. 254-255. 
organization in the world in which moral courage is so profoundly linked with physical courage than the military. Cases of whistle-blowers around the globe have shown that those who possess moral courage often times also require substantial physical courage to step forward. Much more than just losing their jobs is at stake here, even though loss of employment can jeopardize economic existence of entire families, especially when people get "dishonourably discharged" and when their former employers invest a lot of effort to make them "unemployable" for an extended period of time. Furthermore, military uses severe punishments for whistle-blowers, and they are "often penalized more heavily than would seem appropriate considering the harm they did"48. Who knows how many soldiers have died in the field when they expressed dissent and confronted their superiors or group members? Cases of world-famous military whistle-blowers like Bradley Manning and Joe Darby indicate that moral courage can come at the cost of serious physical peril, as both of their lives were in danger when they came forward. In the case of Darby, so much so that he "feared for his life for a while, and lived several years in protective custody at an undisclosed location'49. Not only are whistle-blowers not cowards, they epitomize warrior courage. We cannot but to recall the wise words of Thomas Fuller - "Many would be cowards if they had courage enough".

\section{CONCLUSION}

As we have demonstrated, it is not the lack of intellectual perception nor inability of deeper understanding that prevents soldiers from properly managing loyalty conflicts, rather it is the lack of moral courage. Therefore, some sort of a notion of moral courage must be incorporated in military training and education of all military members. We believe that more emphasis must be put on phronesis or prudentia ${ }^{\mathbf{5 0}}$ within virtue ethics in ethical education of officers, and that it would allow officers to recognize opportunities for excellence outside the realm of physical danger. Officers must be at an intellectual level of thinking that allows them to fully understand these concepts and to possess practical intelligence that enables them to exhibit courage "at the right time, to the right extent, and in the right cause"51. But this shift in approach to training and education is obviously easier said than done. Building group cohesion has been one of the focal points of military training throughout military history as is one of the most important factors of mission success. Unfortunately, it has been proved that there is an inverse relationship between cohesion and moral courage and that "the more socially cohesive a unit, the more prone to a lack of moral courage it is" $\mathbf{5 2}$. There is seemingly a certain

48 Olsthoorn, P. Military Ethics and Virtues, p. 67.

49 Ibid. p. 91.

50 The terms phronesis (Aristotle - $\varphi \rho o ́ v \eta \sigma \iota \varsigma$ ) and prudentia (St. Thomas Aquinas) refers to practical wisdom, prudence, necessary to recognize situations and contexts in which virtue can be displayed.

51 French, S.E. The Code of the Warrior, p. 237.

52 Olsthoorn, P. Military Ethics and Virtues, p. 52. 
paradoxical nuance to this - the more cohesion a group has the more physical courage can be expected from its members, but at the same time less moral courage. But the relationship between physical and moral courage is not a zero-sum game - physical courage can be displayed not only as not shrinking in the face of enemies, but also as not shrinking in the face of dangerous consequences of doing the right thing. The reality is that the nature of the military makes it difficult for moral courage to be appreciated, let alone for it to be placed at the same level as physical courage. Every military in the world has powerful mechanism for ensuring obedience and conformism, meaning that we must come to terms with the fact that militaries are in reality "no bastions of moral courage, and probably never will be" ${ }^{\prime 23}$. But that doesn't mean that things can't improve. We must insist that military education and training focus more on developing moral courage and proper understanding of loyalty, even at the cost of group cohesion. Perhaps such a demanding task should only be attempted in officers' education, as it seems unlikely that such approach would be optimal in military training of conscripts or even non-commissioned personnel. One thing that the military can definitely do is to provide better protection mechanism for those brave enough to speak up for what they believe, for those who remain loyal to their military's tradition and values and their national interests even at the cost of losing everything, including their life. One of the first steps in this challenging direction could be implementation of whistle-blowing case studies in ethical education of officers and cadets, in which the emphasis would be placed on the courage and loyalty displayed by their colleagues, and positive effects of their dissent on all of them. Gaining insight in personal dilemmas, decisions and motivation of those who spoke out could familiarize officers and cadets with whistle-blowers on a more personal level, and help them understand. To go one step further - can't there be a place, and a prominent one for that matter, for heroic whistle-blowers in military history textbooks?

Unfortunately, the military cannot do this alone. Regardless of how isolated from society every military is, it does not exist in a vacuum. In its efforts to raise the awareness about the possible positive effects of whistle-blowing, proper loyalty conflict management, and moral courage the military must be backed up by the entire society, especially policy-makers. There is no reason why military whistle-blowers, whose actions better their organizations and, indirectly, their entire nations, shouldn't be treated as heroes. Positive media coverage and NGO activities are simply not sufficient, albeit they can be very powerful. What is necessary is affirmative action from the top of the political ladder; political leaders must recognize that whistle-blowers in the military can at times contribute, not just to their organizations but also their societies, just as much as those brave soldiers who lay their lives down for their country. This may strike some as controversial or provocative, but if the end goal of any military is to preserve and establish a lasting peace for its nation then all those who contribute to this goal must be respected equally - whether they do it by killing for the sake of peace, willingly dying in this pursuit, or by bravely speaking out for the sake of peace when it is necessary.

53 Ibid. p. 53. 
This article was written as a part of the scientific project of the Military Academy of the Defense University, "Military in the political system of Serbia", financed by the MoD of RS (project no. VA-DH/1/19-21).

Author: Dragan Stanar, PhD, born 1986. He is a Doctor of Philosophy (Military Ethics). Associate Professor at the Faculty of International Politics and Security of the Union Nikola Tesla University in Belgrade and an Adjunct Professor at the Military Academy in Belgrade, where he teaches Military ethics. Teaches Military ethics and moral at the National Defense School of the University of Defense in Belgrade. Member of the Board of Directors of the European Society for Military Ethics (EurolSME). Editor-in-chief of the online Ethics of Peace and War collection on Project Rastko. Fields of research: military ethics, ethics of war, philosophy of violence.

How to cite:STANAR Dragan. Martial Virtues and Whistle-Blowing: Loyalty Misplaced and Courage Misunderstood. 2021, 30 (2), 026-038. ISSN 1210-3292 (print), 2336-2995 (online). Available at: www.vojenskerozhledy.cz 